\title{
AZ INTEGRATÍV VÁROSPOLITIKA TAPASZTALATAI A HAZAI VÁROSTÉRSÉGEKBEN ${ }^{1}$
}

\author{
(Experiences of Integrative City Policy in Domestic City Areas)
}

\section{HERVAINÉ SZABÓ GYÖNGYVÉR}

Kulcsszavak:

integratív politika fenntarthatóság részvétel városi versenyképesség

A tanulmány áttekinti az Európai Unióban kialakult integrativ várospolitikák fäbb jellemzöit, kérdéseit, az ehhez kapcsolódó térségelemzésekben az új tagországokra vonatkozó megállapitásokat. Ezt összeveti kilenc hazai város önkormányzati vezetóivel (fóépitészek, fejlesztési bizottságok vezetöi) és a várostérség 86 önkormányzati vezetöjével készitett kérdőives felmérés eredményeivel. A kutatásokból leszürhetö, hogy a hazai önkormányzatok gyakorlata neoliberális, illetve jórészt tradicionális jellegü, abban kevéssé jelennek meg a részvételi demokrácia és a helyi társadalom kohéziója megteremtésének értékei. Hosszú távon a városfejlödésben áttörést egy koherens nemzeti szintü városfejlesztési program eredményezhet, új társadalmi nézópontokkal és a demokratizmus, szolidaritás értékeinek beemelésével.

\section{Az integrativ várospolitikák az Európai Unióban}

Az európai társadalomfejlődés kiemelt szereplői a városok. Az Európai Unióban egyre inkább teret nyeró policentrikus városfejlesztés elméletét a gyakorlati tapasztalatokat érintő viták egészítik $\mathrm{ki}$. E vitákban hangsúlyossá vált az integratív várospolitikák kérdésköre is, ami napjaink domináns diskurzusává emelkedett. E viták fontos eleme a hagyományos tervezésröl a stratégiai tervezésre való átváltás, a stratégiai tervezésben a részvétel követelményének megjelenése, a környezeti és fenntarthatósági kérdések összekapcsolódása, a fenntarthatóság és integráció szempontjainak felértékelödése. A kérdéskörhöz tartozik a városi kormányzás elméletében a városi menedzsment, mint teljesítményt érintő aspektus, és a jó kormányzás, mint az eltérő csoportok bevonása, képviselete, a helyi politika elszámoltathatósága, integritása és átláthatósága. Ehhez kapcsolódnak a várostérség egészét érintő városgazdasági elméletek, amelyek a városi helyi kormányzás és a városgazdaság kapcsolatrendszerére vonatkoznak (1. táblázat). Az integratív várospolitikák alapvetó kérdése a városi és várostérségi, valamint a részönkormányzati szintek integrálása a településfejlesztésben, azok összekapcsolása a fenntarthatósági célokkal (Pieterse 2004).

$\mathrm{Az}$ integratív várospolitikák számos uniós dokumentumban megjelennek, ide tartozik a Lille program (2000), az EU Koppenhágai Chartája, a milánói, londoni alapelvek, az Európai Parlament Városi Bizottsága létrejötte, a Lipcsei Charta és számos, a városi közpolitikát érintó intézkedés (Lille Action Programme 2000; Lipcsei Charta 2007). 
Hervainé Szabó Gyöngyvér :

Az integratív várospolitika tapasztalatai a hazai várostérségekben.

Tér és Társadalom 22. évf. 2008/1. 77-91. p.

\section{TÁBLÁZAT}

Az integratív várospolitika összetevori

(The Components of Integrative City Policy)

\begin{tabular}{|c|c|c|c|}
\hline \multicolumn{4}{|c|}{$\begin{array}{l}\text { A városkörnyék, város, városi részönkormányzati tervezés összehangolása } \\
\text { Az eltérö tipusú és feladatú, funkcionális stratégiák és programok összehangolása }\end{array}$} \\
\hline \multicolumn{2}{|c|}{$\begin{array}{c}\text { A városvezetés demokratikus aspektusainak } \\
\text { biztositása }\end{array}$} & \multicolumn{2}{|c|}{$\begin{array}{c}\text { A városvezetés teljesitmény aspektusainak } \\
\text { biztositása }\end{array}$} \\
\hline $\begin{array}{c}\text { Képviseleti, } \\
\text { participatív keretek, } \\
\text { a szintek és szektorok } \\
\text { közötti kapcsolatok }\end{array}$ & $\begin{array}{l}\text { Kohézió/politikai } \\
\text { megerösités keret }\end{array}$ & Városmenedzsment & $\begin{array}{l}\text { Versenyképesség } \\
\text { fejlesztése }\end{array}$ \\
\hline $\begin{array}{l}\text { Bevonás a politika } \\
\text { folyamataiba; } \\
\text { A városi jogok } \\
\text { egyenlősége; } \\
\text { Átláthatóság; } \\
\text { Kiszámíthatóság; } \\
\text { A helyi demokrácia } \\
\text { intézményeinek } \\
\text { múködtetése; } \\
\text { A társadalmi moz- } \\
\text { galmak lehetöségei- } \\
\text { nek megteremtése; } \\
\text { A nyelv és hatalom } \\
\text { diszkurzív rendszere- } \\
\text { inek megteremtése; } \\
\text { Az akciók decentra- } \\
\text { lizálása. }\end{array}$ & $\begin{array}{l}\text { Társadalmi egyenlö- } \\
\text { ség: } \\
\text { Városi szolgáltatá- } \\
\text { sokhoz való egyenlö } \\
\text { hozzáférés; } \\
\text { A városi környezet } \\
\text { kiegyenlítettsége; } \\
\text { Társadalmi kapcsolt- } \\
\text { ság (integrálódás a } \\
\text { foglalkoztatás, a } \\
\text { tanulás, az egészség, } \\
\text { a kultúra fóramú } \\
\text { rendszereibe, az } \\
\text { üzleti szféra érdekelt- } \\
\text { té tétele a közösségi } \\
\text { beruházásokban); } \\
\text { Közösségi tervezés } \\
\text { és menedzsment a } \\
\text { szomszédságok } \\
\text { szintjén és a társa- } \\
\text { dalmi rendszer élet- } \\
\text { képessége (bizton- } \\
\text { ság: terrortól, bünö- } \\
\text { zéstől, politikai } \\
\text { zavargásoktól). }\end{array}$ & $\begin{array}{l}\text { A közfelelősség } \\
\text { teljesítés képessége: } \\
\text { A kormányzati és } \\
\text { nem kormányzati } \\
\text { szereplök kapacitá- } \\
\text { sának megteremtése } \\
\text { a közpolitikai prog- } \\
\text { ramok beazonosítá- } \\
\text { sára, alternatívák } \\
\text { kidolgozása az opti- } \\
\text { mális eredmények } \\
\text { elérése érdekében; } \\
\text { Kompetenciák. }\end{array}$ & $\begin{array}{l}\text { A városmenedzs- } \\
\text { ment hajtóeröinek } \\
\text { meghatározása; } \\
\text { Annak megértése, } \\
\text { hogy a városon } \\
\text { belüli térségek sok- } \\
\text { rétü jellege lehetet- } \\
\text { lenné teszi az átfogó } \\
\text { várospolitikát; } \\
\text { Annak megértése, } \\
\text { hogy a városi szintủ } \\
\text { stratégia és az opera- } \\
\text { tív tervek életképes- } \\
\text { sége projekt szinten } \\
\text { kielégítóen kell, } \\
\text { hogy megvalósuljon. } \\
\text { Közszektor me- } \\
\text { nedzsment, jogi } \\
\text { keretek, szolgáltatási } \\
\text { kompetenciák. }\end{array}$ \\
\hline \multicolumn{4}{|c|}{ Versenyképesség és kohézió összekapcsolása } \\
\hline \multicolumn{2}{|c|}{$\begin{array}{l}\text { A szomszédságok beazonosítása. } \\
\text { Integratív szükségletalapú programok. } \\
\text { Akciók: beavatkozás, megakadályozás, } \\
\text { konszolidáció összekapcsolása. } \\
\text { Az iskolák integratív szerepének megteremtése. } \\
\text { A helyi gazdaság szociális elemeinek fejlesztése. } \\
\text { A toleráns együttélés interakciós rendszereinek } \\
\text { kialakítása. } \\
\text { A helyi felelősség rendszereinek érvényesítése. }\end{array}$} & \multicolumn{2}{|c|}{$\begin{array}{l}\text { Az információs technológia menedzsment és } \\
\text { szolgáltatási rendszereinek kialakítása; az } \\
\text { életminőség fejlesztése. } \\
\text { Komplex többszintü kereskedelmi, üzleti } \\
\text { centrumok, alcentrumok kialakítása. } \\
\text { Az illegális szomszédságok legalizálása. } \\
\text { A városi környezet vonzóvá tétele. } \\
\text { Városrehabilitáció. } \\
\text { A lakosság kitelepítése a szlamosodott vá- } \\
\text { rosrészekböl. } \\
\text { Beavatkozás a kritikus szomszédságok fejlö- } \\
\text { dési trendjébe. }\end{array}$} \\
\hline
\end{tabular}

Forrás: Saját szerkesztés. 
A városi integratív politika modellje, szemben a városi növekedés és expanzió elméletekkel az ún. kompakt, azaz a „teljes város” elméletéből fakad. Eszerint a városi közösségi élet olyan nagyságrendjét kell kialakítani, ami lehetóvé teszi a helyi foglalkoztatást, a helyi szolgáltatásokat, a zöld rekreációs területek közelségét, a városi mezőgazdaság elemeit, a földhasználati funkciók helyi közösség által való meghatározását, közepes népsúrúség elérését, megfelelö közterek kialakítását a közösségi élethez, átfogó, emberi léptékủ életkörülményeket. Mindezt oly módon kell megvalósítani, hogy a heterogén közösségek, a marginális csoportok viszonylagos politikai ereje megerősödjön, a dialógusra épülö kommunikatív tervezés rendszere kialakuljon.

Az integratív politika része a pluralista demokratikus részvételen alapuló stratégiai tervezés. A tervezés korábbi centralizált, merev, zónákra építő, statikai alapokon nyugvó rendszerével szemben a stratégiai alapú tervezés válik hangsúlyossá, pluralista demokratikus részvételi keretben és hálózati rendszerben. A fenti uniós dokumentumok kimondják, hogy a várospolitikát három szinten kell kialakítani: a városon belüli szomszédságok, a városi önkormányzat és a várostérségi-regionális szinten. A tervezés stratégiai feladata a város szerepköréből fakadó lehetőségek számba vétele, amelyek egyrészt meghatározzák a gazdasági, társadalmi és kulturális célokat, másrészt koherensek egyéb programokkal és részcélokkal, a városi terület egyes elemeinek dinamikájával, továbbá hatással vannak a város hátországára, és olyan kezdeményezéseket generálnak, amelyek növelik a városok kapesolati kapacitásait.

A városok a lisszaboni célkitüzések kulcsszereplői. Ennek ellenére a tizenötök Európájában is csupán négy országban múködik elfogadott várospolitika, hat esetében a városok a közpolitikában hangsúlyosabbak. A közép-európai térség városainak helyéröl a holland belügyminiszter 2004. november 2-i jelentéséböl szerezhetünk adatokat, amely „Az Európát megerősítő új várospolitika közös keretei” c. elnevezést kapta. E dokumentum szerint a közép-európai országokban a szociális problémák kevésbé markánsak, mint Nyugat-Európa városaiban, bár más problémák ugyanakkor szembetünők: az alapvető fizikai infrastruktúra korlátozott jellege a közlekedést, a lakáshelyzetet, az úthálózatot érintően. Az 1960-90 között épített lakótelepek a legproblematikusabb városi területek, elviselhetetlen a városokban a közlekedés, nincsenek parkolási lehetőségek. A városi hanyatlás legfóbb jele a lakosság vidékre áramlása és a leromlott lakásállomány. Magas a munkanélküliség, a fizikai infrastruktúra és a gazdaság problémái mögött a társadalmi problémák nem jelennek meg a politika színterén. Ugyancsak nem esik szó a társadalom polarizáltságáról.

A jelentés szerint az önkormányzatok nem mérték fel a városi problémákat, ami a fragmentáltságból, a koordináció hiányából és a pénzügyi források hiányából fakadóan a helyi önkormányzatok hatalmi pozícióinak aláásásához vezethet a lokalitás szintjén. Az EU új tagállamainak önkormányzatai nemzeti szinten koordinált várospolitikára tartanak igényt (EU Common... 2004, 12). 


\section{A hazai várostérségek jellemzői az integratív várospolitika szempontjai szerint}

A hazai várostérségek vizsgálata napjaink társadalomfejlődési modelljeinek formálása szempontjából meghatározó. A várostérségi egyenlötlenségek, a várostérségi konfliktusok és versenyképesség kutatása 2005-2007 között, az MTA Szociológiai Intézete koordinálásával zajlott ${ }^{2}$. A kutatás a várostérségi és városi egyenlőtlenségek felmérésében egy kvalitatív interjúsorozattal indult, amelyben a városi vezetés nyolc szereplöjével készítettünk interjút. Emellett a városi és önkormányzati vezetők városfejlesztéssel kapcsolatos attitüdjét vizsgáltuk. Elemzési módszernek a primer adatgyüjtést, ezen belül is a kérdőíves lekérdezést választottuk. A feladat megvalósításához elkészítettük a kérdőivet, majd meghatároztuk a vizsgálatba bevont mintát. A kutatásba bevont városok - Budapest, Debrecen, Győr, Kecskemét, Miskolc, Nyíregyháza, Pécs, Szeged és Székesfehérvár - legfontosabb önkormányzati és civil szereplói mellett a mintába bekerültek a vizsgált városok agglomerációjába tartozó települések, illetve kistérségek önkormányzati vezetöi is. Összesen 105 kérdőívet küldtünk ki, melyből 86 érkezett vissza. A kutatás eredményeinek publikálása részben megtörtént, részben a közeljövőben várható. A megadott válaszok 86 település adatait tükrözik, amelyekböl a többséget kisebb települések adják. A megkérdezettek között jelentösebb súllyal szerepeltek a várostérségeket képviselő települések.

$\mathrm{Az}$ önkormányzati szereplők nézőpontját meghatározza a hazai településszerkezet, az önkormányzati struktúra, a tervezés szabályozottságának fragmentáltsága. Addig, amíg az önkormányzatok az európai uniós programozás kérdései tekintetében kellő ismeretekkel és tapasztalatokkal bírnak, jelentős a részvételük a nemzetközi önkormányzati képviseleti és érdekvédelmi fórumokban. Vezetóik a rendszerváltás első évtizedeiben jelentős intézményfejlesztési programok résztvevői voltak, kevéssé járatosak azokban az új programokban és modellekben, amelyek a fejlett térségek önkormányzatait, az önkormányzati menedzsment fejlesztési kérdéseit érintik. Mindez talán azzal is összekapcsolható, hogy az új évezred magyar önkormányzati diskurzusait nem a fejlesztés kérdései, hanem a közigazgatási rendszer átalakításának vitái határozták meg.

A hazai városok fejlődéséról szóló viták a regionális tudományosság keretei között maradtak, a hazai urbanisztika a városfejlesztés modelljeinek közvetítésében kevéssé bizonyult sikeresnek. Ezért akkor, amikor az európai modellek ismeretét, alkalmazását kutatjuk, számolnunk kell azzal a problémával, hogy e modellek nem igazán jelentek meg sem a minisztériumi igazgatási, sem a városi szövetségek, egyéb önkormányzati szövetségek dokumentumaiban. Az új programok csak a szaklapok fórumain kaphattak teret, ami azt eredményezte, hogy az integratív politikák többnyire alulról jövő, ösztönös kezdeményezések lehettek. 


\section{A részvételi tervezés kérdései}

A tervezés keretei és szintjei Magyarországon is jogilag szabályozottak, és más településekkel, kistérségekkel a tervezési koordináció legfeljebb önkéntes, szükségletből fakadó vagy funkcionális (pályázati feltétel) lehet. A participatív tervezés számos esetben kiterjed más önkormányzatokra (Miskolc, Nyíregyháza, Székesfehérvár), gazdasági szereplökkel való együttmüködésre, fejlesztési társaságokra (Székesfehérvár, Nyíregyháza), európai együttmüködést Nyíregyháza említett, míg a civil szervezetekre, kamarákra, szakmai szervezetekre, Pécs, Miskolc, Nyíregyháza, Debrecen és Székesfehérvár is utalt. A városfejlesztés tervezésében számos esetben hiányolt az átfogó racionális tervezés rendszere (fragmentált tervezési rendszer), a haszoncélú tervezés (a kisközösségek érdekeinek figyelembe vétele), és úgy tünik, dominál az érdekalapú (befektetői csoportokra építö) tervezés. A városok és környezetük konfliktusai (közlekedési anomáliák, a városi szolgáltatások alacsonyabb árai, az oktatási infrastruktúra konfliktusai, az aszimetrikus hatalmi viszonyok, a képzettebb lakossági csoportokért való küzdelem stb.) nem csupán az összehangolt fejlesztések, hanem a kommunikatív tervezések hiảnyára is utalnak. A városkörnyék tervezési problémái között a vizsgált nagyvárosok környékén is érezhetö a városi nyomás alatti fejlödés problematikussága, míg az alföldi városok megfogalmazzák a dunántúli városok túldimenzionáltságát a keleti végek kárára, azaz a versenyképességből való kiszorítottság problémáját.

\section{A városok belső polarizációjából fakadó problémák}

A városvezetés részéröl a szegényebb és sebezhetőbb csoportok megerősítése, a társadalmi kohéziót erősítő törekvések eltérỏ eredményt mutatnak a kvalitatív interjúk és a kérdőívekből kirajzolódó normatív politikai törekvéseket illetően. Míg az interjúk mélyen érintik a városi külterületi lakosság okozta problémákat, a cigánykérdés rendezetlenségét, a szociális bérlakások hiányát, a szociális szolgáltató intézetek elhelyezkedését, a koldulás kérdéseit, addig a kérdőivekben az életminöség kap kiemelt szerepet. Az életminöség kérdésében sajátos, hogy első helyre kerül az, hogy szeressenek az emberek a városban élni, második a környezet és tisztaság, harmadik a közbiztonság kérdése. Erőteljes a küzdelem a lakosság középosztályi csoportjainak növeléséért, felerősödött a várostérségi kistelepülések és a városok küzdelme általában a lakosság létszáma növeléséért (Szeged esetében fogalmazódtak meg a lakosság kiköltözése miatti ellenérzések). Összességében 7 város számára jelentett érzékelhető problémát a cigány lakosság kezelése, ami nem egyszer párosult esszencialista megoldásokkal (romatelepek felszámolása a lakosság kitelepitésével). Több esetben mond ellent a normatív várospolitikáknak a külterületi lakosság helyzetének rendezetlensége, ivóvíz-ellátásának hiánya, iskolabezárások, az, hogy a külterületen élők kiesnek a segélyezésböl és a jövedelempótló támogatásokból, erőteljes az infrastrukturális nyomás egyes városokban a külterületi „,balkáni” 
állapotok miatt. Mindez aligha utal a környezeti igazságosság kérdésének norma szintủ elfogadottságára.

Akadt olyan város, amelyben megfogalmazódott, azok lakjanak a városban, akik képesek megfizetni szolgáltatásait. Legkevésbé számítanak a roma lakosság integrációjára, a nyugdíjas csoportok integrálására a várospolitikában, a szegény rétegek csökkenésére, és kevéssé valószinúnek látják a fiatal lakossági csoportok várospolitikába való integrációját. A közmunka programok $(3,3)$, a szegénység elleni programok $(3,01)$, speciális társadalmi csoportok célzott támogatása, települési szociális programok $(3,2)$, munkahelymegtartó támogatások pár tized ponttal magasabbra értékeltettek, mint a szociális gazdaság ösztönzése, a lakásprogramok, az adósságkezelési programok.

A városi kohéziós politika kifejezés kevéssé van jelen a helyi politika diskurzusaiban, helyette a helyi fejlesztés a domináns. A kohéziós politikai tevékenység nehezen értékelhetö, mivel az elmúlt 16 évben nem a leszakadás megakadályozása, hanem a gazdasági-társadalmi átmenet programjai domináltak. Az érintett városok vezetői a városi belső kohéziós tevékenységek gazdaság fejlesztéséhez kötődö kapcsolatait alig látják, alig értelmezik, nézőpontjukban viszonylag túlzott a szerepe a tervezési, programozási tevékenységeknek, mindenekelött az önkormányzatok tulajdonosi viselkedésének. A szegénységgel és annak kezelésével kapcsolatos feladatokat alulértékelik, többnyire tanácstalanok a társadalmi problémák kezelésében.

Több városvezető (pl. Szeged, Székesfehérvár térsége) véleménye összecseng, miszerint egy közös iroda Brüsszelben, illetve az ipari park-fejlesztések, valamint a felsőoktatás fejlesztése nem járul hozzá a társadalmi egyenlőtlenségek orvoslásához. Szinte minden önkormányzat véleménye megegyezik abban, hogy az egyenlötlenségek megoldásához inkább állami és uniós forrásokra van szükség, melyek lehetővé teszik a városok számára speciális projektek megvalósítását a társadalmi különbségek oldása érdekében.

A városok többsége úgy látja, hogy az elmaradottabb települések felzárkózását szociális alapon nyújtott támogatásokkal lehetne felgyorsítani. E vélemény képviselöi között van például Szeged, Győr és Székesfehérvár. Napjainkban tehát kiemelt fontosságúnak tartják a magyar városok az állam szerepét a szociális kérdések rendezésének terén. Mindannyian egyetértenek abban, hogy a jelenlegi állami szerepvállalás mértéke folyamatosan erősödik, és nagyobb jelentöséggel bír majd a jövöben. A településfejlesztésben a társadalmi szempontokat legkevésbé Pécs és környéke, leginkább Kecskemét, Miskolc, Nyíregyháza tartja fontosnak. Jellemző, hogy Pécs és Szeged várostérségében adnak a legkisebb szerepet az egyenlőtlenségek csökkentésének, míg Miskolcon ezt a tényezöt magasra értékelik.

\section{A városvezetés menedzsment kvalitásai}

A kilenc várostérség önkormányzatai a várospolitikai menedzsment eszközeiben elsô helyre állitották a költségvetést, az adóbevételeket, mint eszközöket, ezt követte a fog- 
lalkoztatottság, a polgármesteri hivatal kapacitása, az oktatási intézmények eloszlása, képzési orientációja; a legkevesebb értéket a civil szervezetek szerepvállalása kapta. A városmenedzsment eszközök az 5 fokú skálán alig érik el a 3 pontot: leginkább a fejlesztési stratégiákban, az önkormányzati tulajdon értékesítésében, egyes településrészek környezetfejlesztésében látnak lehetöséget. A humán tényezöben legmagasabbra értékelt az egészségügy, az alapfokú és közoktatás, jellemzően a városvezetök alulértékelik a kutatással, fejlesztéssel, felsóoktatással foglalkozó kérdéseket.

A településmenedzsment kérdéseiben az önkormányzattal szemben alulértékelt az állami cselekvés, a regionális szint és a megyei szint, a politika skáláit illetỏen egyértelmủ az önkormányzati szint túldimenzionált jellege. Az uniós szint nem éri el a 3 pontot. Különösen Szeged és Debrecen értékelte magasra a város funkcióit, a megye legmagasabb értéket Székesfehérvár, Miskolc és Győr esetében kapott, Székesfehérvár és Miskolc a régió jövőbeni lehetőségeit látta fontosnak. Az állam szerepe mindenütt a 4 . helyre került. A kapacitások között messze hangsúlyosabb a pénzforrások szerepe, általában leértékelt a szervezeti kapacitás.

Az önkormányzatok legfontosabb közfeladatuknak a szociális feladatok ellátását tartják, ezen belül is nagy hangsúlyt fektetnek a gyermekek és idősek ellátására. Ezt követően fogalmazódnak meg az önkormányzat szervezeti felépítését érintő közpolitikai feladatok, és csak utolsó sorban szerepel a lakosság megelégedettségét szem elött tartó feladatok ellátása (fogadóórák, ügyintézési rend fejlesztése, a képviselök felkészítése) (2. táblázat).

\section{TÁBLÁZAT}

A szolgáltatási kapacitás fejlesztésének kérdései a hazai várostérségekben (Questions of Improving Capacity of Service in Domestic City Areas)

\begin{tabular}{lcc}
\hline \multicolumn{1}{c}{ A szolgáltatási funkció neve } & $\begin{array}{c}\text { Jelenlegi } \\
\text { gyakorlat }\end{array}$ & Lehetöség \\
\hline Különböző társadalmi csoportok igényeinek kezelése & 3,01 & 3,61 \\
Képviselök felkészítése & 2,96 & 4,13 \\
Információszerzés rendszerének kialakítása a helyi & 2,86 & 3,63 \\
konfliktusokról & 2,75 & 3,53 \\
Képviselök számának csökkentése & 2,74 & 3,41 \\
Polgármesteri hivatal létszámfejlesztése & 2,49 & 3,30 \\
Egyablakos ügyintézési rendszer & 2,44 & 2,97 \\
Képviselői fogadások problémáinak elemzése & 2,09 & 3,27 \\
Elektronikus fogadóórák & & \\
\hline
\end{tabular}

Forrás: Saját szerkesztés.

A települések által nyủjtott szolgáltatások színvonala a szereplők szerint nem megfelelö, ezért e területen is további fejlesztésekre van szükség. Jelenleg és a jövőben is várhatóan inkább a szolgáltatások nyújtását segítő infrastruktúra fejlesztése élvez prioritást. A szolgáltatási tájékoztatók, az információs szolgáltatási kapacitás fejlesztése, az e-szolgáltatási rendszer, az egészségügyi és szociális térképek inkább csak a jövő kapacitásaiban kapnak szerepet. Alapvetỏen leértékelt a szolgál- 
Tér és Társadalom 22. évf. 2008/1. 77-91. p.

tatások kiszerződése és minőségellenőrzése, és egyáltalán nem elfogadott, hogy egyik önkormányzat a másiknak vállalkozói jelleggel nyújtson szolgáltatásokat.

Az önkormányzatok tudáskapacitása a településfejlesztésben nagyon meghatározó. A települések többsége úgy véli, hogy ennek egyik kulcsszereplöje a polgármester, sok múlik az ő munkáján. A városvezető felkészültsége, kvalifikáltsága a település fejlödésének egyik legfontosabb tényezőjeként értékelt. Kiemeltek a polgármester személyes kvalitásai $(4,47)$, tájékozottsága a tervezési folyamatokról, a társulásokban való részvétel $(4,1)$, ezzel szemben a minőségbiztosítási rendszer kialakítása $(3,6)$, a pályázati iroda léte $(3,3)$, fuiggetlen fejlesztési csoport léte $(3,1)$, a nemzetközi kapcsolatok iroda léte $(2,93)$ alulértékelt.

\section{A városok és a versenyképességi politika}

A kutatás számos támpontot adott arra vonatkozóan, milyen a vizsgált térségekben a városok és várostérségi önkormányzatok vezetőinek felfogása a település versenyképessége fejlesztését illetően.

A várostérségek versenyképességére, fenntartható fejlódésére az önkormányzatok a településmarketing révén tudnak leginkább hatni. A vizsgált térségekben az önkormányzati fejlesztésekre helyeződik a legnagyobb hangsúly, a városi környezet formálása és az infrastrukturális megújulás van a fejlesztések fókuszában. Ezt követik a társadalmi szempontok, a közszolgáltatások színvonalának javítása és az élhetőbb környezet kialakítása a várostérségekben. A helyi elit tehát láthatóan a társadalmi-szociális szempontokat fontosabbnak értékeli, mint a gazdasági szempontokat. A fenti célkitüzések az említett európai dokumentumok megállapításai alapján helytállóak. A legmagasabb pontokat és értéket az önkormányzati fejlesztések kapták, azaz az önkormányzat, mint legfontosabb beruházó és fejlesztő erő jelenik meg. Különösen Miskolc és Nyíregyháza térségében kapott magas értéket, emellett Székesfehérváron tulajdonítanak neki kiemelkedő szerepet.

A településfejlesztés gazdasági elemei között a nemzetközi gazdasági szereplök vonzása, a helyi gazdasági szereplók támogatása, a versenyképesség növelése alulértékelt. A legalacsonyabb értéket a nemzetközi szereplök vonzása kapta, ám komoly eltérések vannak várostérségenként. Nyíregyháza a külföldi tőkét 4,5 pontra értékeli, míg Kecskemét 2,3-ra. E vonatkozásban tanulságos, hogy Pécs és Székesfehérvár térségének települései is alacsony értéket adnak a külföldi tőkének, ám nyilvánvalóan más megfontolások alapján.

Egyértelmüen kitapintható, hogy a településfejlesztés gazdasági elemei között a hangsúly a helyi gazdasági szereplökön van. Nyíregyháza esetében az érték elérte az ötöt, ám Pécs esetében is legalább 3,5 a települési önkormányzatok által adott érték. Szeged, Székesfehérvár, Miskolc, Kecskemét egyaránt magasra értékeli a helyi vállalkozások támogatását. A fenti célok megegyeznek a holisztikus célkitüzésekkel, amelyek a helyi foglalkoztatást hangsúlyozzák. 


\section{TÁBLÁZAT}

A településfejlesztés eszközrendszere, prioritásai (The Approach System and Priorities of Settlement Development)

\begin{tabular}{|c|c|c|c|}
\hline & A településfejlesztés eszközrendszere & Jelenlegi & Jövöbeni \\
\hline \multirow{9}{*}{ 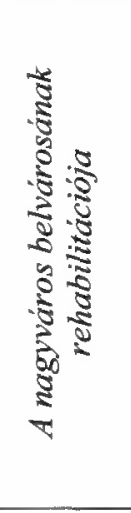 } & $\begin{array}{l}\text { Városközpontot védö korlátozások hátrányai- } \\
\text { nak leküzdése }\end{array}$ & 3,11 & 3,49 \\
\hline & $\begin{array}{l}\text { Városközpont rehabilitációját biztosító szabá- } \\
\text { lyozás }\end{array}$ & 3,54 & 3,94 \\
\hline & $\begin{array}{l}\text { Rehabilitációval kapcsolatos társadalmi ér- } \\
\text { dekviszonyok feltárása }\end{array}$ & 3,18 & 3,70 \\
\hline & Lakásfelújítás & 3,27 & 3,66 \\
\hline & Magántőke bevonása & 3,35 & 3,62 \\
\hline & Múemlékek védelme & 3,54 & 3,94 \\
\hline & Gyalogos zónák kialakítása & 3,30 & 3,79 \\
\hline & Közlekedés átszervezése & 3,30 & 4,10 \\
\hline & $\begin{array}{l}\text { Egységes hatósági belváros-rehabilitációs } \\
\text { koncepció }\end{array}$ & 3,14 & 3,75 \\
\hline \multirow{8}{*}{ 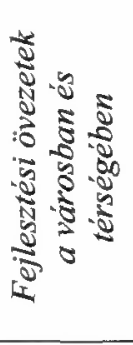 } & Ipari parkszerü ipari ökológiai rendszerek & 3,00 & 3,76 \\
\hline & Üzleti szolgáltató központok & 3,41 & 3,56 \\
\hline & Kulturális befektetési és szolgáltató központok & 3,31 & 4,04 \\
\hline & Iskolanegyedek, kampuszok kialakítása & 2,89 & 3,44 \\
\hline & Repülőtér kialakítása, fejlesztése & 2,67 & 3,40 \\
\hline & Konferenciaközpontok létrehozása & 2,80 & 3,81 \\
\hline & Inkubációs szolgáltató központok & 2,44 & 3,46 \\
\hline & Technológiatranszfer központok & 2,41 & 3,28 \\
\hline \multirow{7}{*}{ 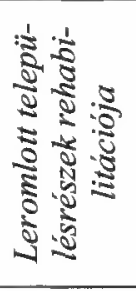 } & Lakó- és munkahely integrált fejlesztése & 2,88 & 3,74 \\
\hline & Komplett infrastruktúrafejlesztés & 3,28 & 4,00 \\
\hline & Lakásfejlesztés (apartman-központok stb.) & 3,12 & 3,75 \\
\hline & Oktatási szolgáltatások betelepítése & 3,07 & 3,94 \\
\hline & Szociális-gazdasági szervezetek vonzása & 3,13 & 3,92 \\
\hline & Alternatív kulturális-szabadidős szolgáltatások & 3,15 & 3,94 \\
\hline & Új közlekedési struktúra & 3,05 & 4,13 \\
\hline \multirow{7}{*}{ 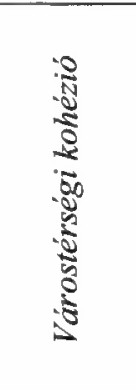 } & Speciális térségi szolgáltatások & 2,73 & 3,69 \\
\hline & Üzleti, technológiai parkok & 2,72 & 3,60 \\
\hline & Integrált agglomerációs közlekedés & 2,95 & 4,00 \\
\hline & $\begin{array}{l}\text { Várostérségi fejlesztés szervezeti formáinak } \\
\text { kialakítása }\end{array}$ & 2,71 & 3,68 \\
\hline & $\begin{array}{l}\text { Városkörnyéki és városi szolgáltatások ösz- } \\
\text { szehangolása }\end{array}$ & 2,78 & 3,95 \\
\hline & $\begin{array}{l}\text { Kistelepülési konszolidáció munkahelyterem- } \\
\text { tés révén }\end{array}$ & 2,56 & 3,65 \\
\hline & Farmgazdálkodási rendszerek fejlesztése & 2,05 & 3,23 \\
\hline
\end{tabular}

Forrás: Saját szerkesztés. 
A kérdőiv a gazdaságfejlesztés leggyakrabban használt célterületére kérdezett rá: külső vagy belső erők, a gazdasági együttműködések és a lokális vonzerők, a turizmus lehetöségeire. Meglepő módon a válaszadók, Nyíregyháza kivételével, szinte minden városban alulértékelték a felsőoktatás, illetve a kutatás-fejlesztés versenyképességre ható szerepét, valamint nem tartották fontosnak a politikai stabilitást sem. E kérdéscsoporton belül arra derült fény a válaszokból, hogy a helyi politikai elit véleménye szerint sokkal fontosabbak a szociális szempontok, például az, hogy szeressenek ott élni az emberek és biztonságban érezhessék magukat. Ez következik a kérdésekre adott válaszok eredményeinek átlagából is. Elsődleges az életminőség, másodlagos a helyi kormányzás intézményrendszere és legkevésbé jellemző a külső integráltság, a tudástársadalom, illetve a szociális egyenlőtlenségek mérséklése.

A településfejlesztés eszközrendszerének fontossági rangsora a megkérdezettek véleménye szerint eltéró. Valójában e kérdéscsoport mögött a prioritások húzódnak meg, a várostérségek fejlesztésének eltérő koncepcióit tükrözik. Amennyiben a hangsúly az első blokkra esik, úgy egy polgári középosztályos fejlesztési modell, a második esetében egy modernista településfejlesztés, a harmadik esetében egy posztmodern modell rajzolódik ki, míg a negyedik egy életstílus alapú fenntartható fejlesztés rendszereit kombinálja (3. táblázat).

Nyíregyháza, Budapest, Pécs, Kecskemét viszonylag magasabb pontszámokat adott a belvárosok fejlesztési lehetőségeinek, ám szkeptikus a magántőke bevonása, az egységes hatósági belváros-rehabilitációs koncepciók iránt. A modernista típusú fejlesztésre leginkább az üzleti szolgáltató, a kulturális befektetési és szolgáltató központoknak adnak lehetóséget, különösen alacsony értéket adtak az ipari parkszerủ ipari ökológiai rendszereknek, az iskola-negyedeknek, a repülőterek kialakításának, az inkubációs központoknak.

A 4. táblázatban jól látható, hogy a megkérdezettek véleménye szerint mely infrastrukturális fejlesztések hol állnak a fontossági rangsorban. A településrészek rehabilitációja alig ismert lehetőség, mindösszesen a komplett infrastruktúrafejlesztés és a közlekedési infrastruktúrafejlesztés kaptak magasabb értékeket.

A várostérségi kohézió erősítésében hangsúlyos a városi és vidéki szolgáltatások összehangolása, ugyanakkor nem tulajdonítanak kellő fontosságot az uzleti technológiai parkoknak, a városfejlesztés szervezeti formáinak, a munkahelyteremtésnek és a farmgazdálkodásnak. Összességében a kutatott várostérségek többségében a fejlesztés modelljei tradicionális, alulfejlett attitüdöt és kevéssé endogén, belső forrásokra építő gyakorlatot tükröznek. 


\section{TÁBLÁZAT}

Az infrastrukturális fejlesztések fontossága

(Significance of Infrastructural Developments)

\begin{tabular}{|c|c|c|c|}
\hline $\begin{array}{l}\text { Városközpont rehabilitációját } \\
\text { biztosító szabályozás meg- } \\
\text { teremtése }\end{array}$ & 3,54 & Új közlekedési struktúra & 4,13 \\
\hline Mủemlékek védelme & 3,54 & Közlekedés átszervezése & 4,10 \\
\hline Üzleti szolgáltató központok & 3,41 & $\begin{array}{l}\text { Kulturális befektetési és szol- } \\
\text { gáltató központok }\end{array}$ & 4,04 \\
\hline Magántőke bevonása & 3,35 & $\begin{array}{l}\text { Komplett infrastruktúrafejlesz- } \\
\text { tés }\end{array}$ & 4,00 \\
\hline $\begin{array}{l}\text { Kulturális befektetési és szol- } \\
\text { gáltató központok }\end{array}$ & 3,31 & $\begin{array}{l}\text { Integrált agglomerációs közle- } \\
\text { kedés }\end{array}$ & 4,00 \\
\hline Gyalogos zónák kialakítása & 3,30 & $\begin{array}{l}\text { Városkörnyéki és városi szol- } \\
\text { gáltatások összehangolása }\end{array}$ & 3,95 \\
\hline Közlekedés átszervezése & 3,30 & $\begin{array}{l}\text { Városközpont rehabilitációját } \\
\text { biztosító szabályozás megte- } \\
\text { remtése }\end{array}$ & 3,94 \\
\hline Komplett infrastruktúrafejlesztés & 3,28 & lékek védelme & 3,94 \\
\hline Lakásfelújitás & 3,27 & $\begin{array}{l}\text { tási szolgáltatások betele- } \\
\text { e }\end{array}$ & 3,94 \\
\hline $\begin{array}{l}\text { Rehabilitációval kapcsolatos } \\
\text { társadalmi érdekviszonyok fel- } \\
\text { tárása }\end{array}$ & 3,18 & $\begin{array}{l}\text { Alternatív kulturális-szabadidős } \\
\text { szolgáltatások }\end{array}$ & 3,94 \\
\hline $\begin{array}{l}\text { lternatív kulturális-szabadidós } \\
\text { olgáltatások }\end{array}$ & 3,15 & $\begin{array}{l}\text { Szociális-gazdasági szervezetek } \\
\text { vonzása }\end{array}$ & 3,92 \\
\hline $\begin{array}{l}\text { gységes hatósági belváros- } \\
\text { habilitációs koncepció }\end{array}$ & 3,14 & $\begin{array}{l}\text { Konferenciaközpontok létreho- } \\
\text { zása }\end{array}$ & 3,81 \\
\hline $\begin{array}{l}\text { zociális-gazdasági szervezetek } \\
\text { onzása }\end{array}$ & 3,13 & Gyalogos zónák kialakitása & 3,79 \\
\hline $\begin{array}{l}\text { Lakásfejlesztés (apartman- } \\
\text { központok stb.) }\end{array}$ & 3,12 & $\begin{array}{l}\text { zszerủ ipari ökológiai } \\
\mathrm{k}\end{array}$ & 3,76 \\
\hline t védő korlátozá- & 3,11 & $\begin{array}{l}\text { Egységes hatósági belváros- } \\
\text { rehabilitációs koncepció }\end{array}$ & 3,75 \\
\hline $\begin{array}{l}\text { Oktatási szolgáltatások betelepí- } \\
\text { tése }\end{array}$ & 3,07 & $\begin{array}{l}\text { Lakásfejlesztés (apartman- } \\
\text { központok stb.) }\end{array}$ & 3,75 \\
\hline Új közlekedési struktúra & 3,05 & $\begin{array}{l}\text { Lakó- és munkahely integrált } \\
\text { fejlesztése }\end{array}$ & 3,74 \\
\hline $\begin{array}{l}\text { Ipari parkszerü ipari ökológiai } \\
\text { rendszerek }\end{array}$ & 3,00 & $\begin{array}{l}\text { Rehabilitációval kapcsolatos } \\
\text { társadalmi érdekviszonyok } \\
\text { feltárása }\end{array}$ & 3,70 \\
\hline $\begin{array}{l}\text { Integrált agglomerációs közle- } \\
\text { kedés }\end{array}$ & 2,95 & $\begin{array}{l}\text { Speciális térségi szolgáltatások } \\
\text { (pl. iskolabusz, lakásszövetke- } \\
\text { zet, rendfenntartás) }\end{array}$ & 3,69 \\
\hline $\begin{array}{l}\text { Iskola } \\
\text { kialak }\end{array}$ & 2,89 & $\begin{array}{l}\text { Várostérségi fejlesztés szerve- } \\
\text { zeti formáinak kialakítása }\end{array}$ & 3,68 \\
\hline
\end{tabular}


Tér és Társadalom 22. évf. 2008/1. 77-91. p.

\begin{tabular}{|c|c|c|c|}
\hline $\begin{array}{l}\text { Lakó- és munkahely integrált } \\
\text { fejlesztése }\end{array}$ & 2,88 & Lakásfelújítás & 3,66 \\
\hline $\begin{array}{l}\text { Konferenciaközpontok létreho- } \\
\text { zása }\end{array}$ & 2,80 & $\begin{array}{l}\text { Kistelepülési konszolidáció } \\
\text { munkahelyteremtés révén }\end{array}$ & 3,65 \\
\hline $\begin{array}{l}\text { Városkörnyéki és városi szolgál- } \\
\text { tatások összehangolása }\end{array}$ & 2,78 & Magántőke bevonása & 3,62 \\
\hline $\begin{array}{l}\text { Speciális térségi szolgáltatások } \\
\text { (pl. iskolabusz, lakásszövetke- } \\
\text { zet, rendfenntartás) }\end{array}$ & 2,73 & Üzleti, technológiai parkok & 3,60 \\
\hline Üzleti, technológiai parkok & 2,72 & Üzleti szolgáltató központok & 3,56 \\
\hline $\begin{array}{l}\text { Várostérségi fejlesztés szervezeti } \\
\text { formáinak kialakítása }\end{array}$ & 2,71 & $\begin{array}{l}\text { Városközpontot védỏ korlátozá- } \\
\text { sok hátrányainak leküzdése }\end{array}$ & 3,49 \\
\hline Repülőtér kialakítása, fejlesztése & 2,67 & Inkubációs szolgáltató központok & 3,46 \\
\hline $\begin{array}{l}\text { Kistelepülési konszolidáció } \\
\text { munkahelyteremtés révén }\end{array}$ & 2,56 & $\begin{array}{l}\text { Iskolanegyedek, kampuszok } \\
\text { kialakítása }\end{array}$ & 3,44 \\
\hline Inkubációs szolgáltató központok & 2,44 & Repülötér kialakítása, fejlesztése & 3,40 \\
\hline Technológiatranszfer központok & 2,41 & Technológiatranszfer központok & 3,28 \\
\hline $\begin{array}{l}\text { Farmgazdálkodási rendszerek } \\
\text { fejlesztése }\end{array}$ & 2,05 & $\begin{array}{l}\text { Farmgazdálkodási rendszerek } \\
\text { fejlesztése }\end{array}$ & 3,23 \\
\hline
\end{tabular}

Forrás: Saját szerkesztés.

\section{Összegzés}

A hazai kutatásban érintett várostérségek integrativ politikai kultúrájának kibontakozása megkezdődött, jellemzői az alábbiakban foglalhatók össze:

1) Az önkormányzati interjúk a városfejlesztés, a várostérségi konfliktusokat illetően nem említettek integratív programokat, akciókat, a szomszédságokig lemenő fejlesztési megoldásokat. Az integratív politikák kibontakozásának fontos gátja a tervezés fragmentáltsága, a koherens városvízió modellek ismeretének jelen nem léte, a nemzetközi tapasztalatok hiánya. A hazai település és városszövetségek, a felügyelő minisztériumok inkább a fragmentált önkormányzati szerkezet anomáliáinak kezelésére helyezték a hangsúlyt, közel egy évtized ráment a közigazgatás reformjára (eredmények nélkül) és a hazai közegben vitatott regionális törekvésekre. Ugyanakkor a regionális tervezésre helyezett hangsúly mögơtt nem jelentek meg a hazai viszonyoknak jobban megfelelö városrégió modellekről szóló diskurzusok, azok a hazai tudományosság perifériảjára szorultak.

A hazai lokális politikai elit (a polgármester parlamenti képviselők, a fejlesztésigazgatás szereplői) a közpolitika komparatív kutatásának hazai alulfejlettsége miatt kevéssé ismerik az európai várospolitikák eredményeit, nem tehettek kísérletet azok trendjeinek adoptálására, a hazai városfejlesztés problémáinak új módszerekkel való kezelésére. A hazai önkormányzati képviselet az EU és ET intézményeiben megfelelö, a nemzetközi önkormảnyzati szervezetekben szerzett tapasztalatokat illetően azonban nem hatékony a tudásfolyamatok áramoltatásában. 
2) A városfejlesztés kultúrája alacsony stratégiai menedzsment kompetenciákat mutat, melynek oka az, hogy a fejlesztési kompetencia és jogosultság nem a várostérségek, hanem a régiók stratégiai programalkotásába került, hiányoznak az ilyen osztályok, szakemberek. A várostérségi integratív politikákban a versenyképesség és a városi és várostérségi kohézió kérdései összemosódnak. Az európai gyakorlatban elfogadott értékek és alapelvek alig köszönnek vissza: nem kimondott alapelv a szolgáltatásokhoz való egyenlő hozzáférés, a városi környezet kiegyenlítése, a közösségi menedzsment értékeinek beépítése. Különösen feltünö a romák integrációjáról való lemondás. Ritka esetben figyelnek a városkörnyékre. Számos esetben jóval inkább érték a város szigetszerü fejlődése. A városvezetésben e törekvések elfogadott normákká alakítása csakis akkor lehetséges, ha nemzeti szintü közpolitikai programok azokat beviszik a napi politika normái közé.

3) A városmenedzsment kérdéseire adott válaszok arra utalnak, hogy az önkormányzatok nem építenek, nem építhetnek a partnerségi struktúrákra, a partnerek tudására és közpolitikai felelősségének megteremtésére. A közép-európai fejlödés sajátossága a civil szféra gyenge jelenléte, marginális szerepe. E szektor fejlesztésének gátját jelenti az önkormányzati szféra szerepének túlhangsúlyozása. Az önkormányzatok szerepköre és a privatizált szolgáltatások közötti diszkrepancia arra utal, hogy az önkormányzatok a tradicionális várospolitika és kevéssé az új városkormányzási modellek hívei.

A városi integratív politikák alapján a legföbbnek tartott hajtóerő az önkormányzat, második a helyi vállalkozói szektor, a szereplök között leértékelt a multinacionális vállalkozások szerepe. A versenyképesség hajtóerőinek szükségességét kevéssé értette meg az önkormányzati szféra, és a KKV-k szerepét is tradicionálisan értelmezte. Az önkormányzatok kevéssé érzik felelősnek magukat a foglalkoztatásért.

4) Bár sok város és térsége felismerte már a váltás kényszerét, de lépéseik még bizonytalanok, óvatosak. Több esetben megfogalmazódott a leromlott várostérségek rehabilitációja iránti igény, számos városban (Székesfehérvár, Győr, Debrecen) már konkrét lépések is történtek.

Jelentős szemléletváltásra van azonban szükség a $\mathrm{K}+\mathrm{F}$ és az oktatás értékelésében is.

A magyar várostérségeknek is be kell látniuk, hogy a tradicionális önkormányzati feladatok mellett (pl. szociális ellátások) egyre nagyobb figyelmet kell szentelni a gazdaság fejlesztését szolgáló egyéb szempontokra is. Ma egy térség versenyképességének nem a naturális mutatók a mércéi (pl. munkahelyek száma, vállalkozások száma, kibocsátás, adóbevétel), hanem egyre fontosabbá válnak az olyan minöségi tényezők, mint a város oktatási kínálata, kutatási- és fejlesztési színvonala, a vállalkozások innovációs készsége, együttmüködése.

A várostérségek politikai elitjében már megfogalmazódtak ezek a problémák, de intézkedések csak néhány helyen, lassan történnek. Ennek egyik oka a kapcsolatok hiánya. Kialakulóban van az együttmúködés az egyes önkormányzatok, a térség egyéb gazdasági szereplöi, egyéb intézményei között. A kilenc várostérség szerepe a hazai versenyképesség vonatkozásában kiemelt: fejlesztésük, más nem vizsgált várostérségekkel együtt nemzeti szükségszerüség. A hazai városok vezetői azt meg- 
tették, ami az önkormányzati törvényböl fakadóan megvalósítható. Tudásuk, ismereteik, attitüdjük alkalmas volt a rendszerváltás folyamatában a városok új pályára való állításához. Ahhoz, hogy a várostérségek integrált fejlödése minőségi nagyságrenddel változzon, nem elegendők az egydimenziós programok, szükség van a sikeres nemzetközi modellekböl a hazai viszonyok esetében is realizálható koherens várospolitika kialakítására. Szükség van olyan társadalmi diskurzusokra, amelyek az inkluzivitás, a szegény és marginális csoportok helyzete megváltoztatásának célkitüzéseit a városi közélet normatív követelményévé teszik, melyek között a város és városkörnyék lakossága egyenlötlenségével szemben magasabb értéke van egy igazságosabb helyi társadalom kialakításának.

\section{Jegyzetek}

1 Az NKFP Várostérségi egyenlötlenségek és versenyképesség kutatási programja részeredményei (2005-2007).

2 A kutatás partnerei között az MTA RKK Székesfehérvári Csoportja, a Kodolányi János Főiskola Szociális Tanulmányok Tanszéke, valamint a Pestterv Kft. szerepeltek. A kutatást Szirmai Viktória professzorasszony vezette.

\section{Irodalom}

Common framework on Future Urban Policy Cities Empower Europe. (2004) Ministry of Interior and Kingdom Relations, The Netherlands. 02/11/2004 http:/www.minbzk.nl/contents/pages/522/ commonframework.pdf

EU Common framework on future urban policy. (2004) Vities empower Europe.

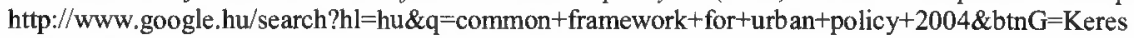
$\% \mathrm{C} 3 \% \mathrm{~A} 9 \mathrm{~s} \&$ meta $=$

Lille Action Programme. (2000) Proposal for a multiannual programme of co-operation in urban policy within the European Union. Report by the Committee of Spatial Development. Marseilles. 6. Oct. 2000. http://www.eukn.org/eukn/themes/Urban_Policy/lille-action-programme_1108.html

Lipcsei Charta (én.) http://www.mut.hu/dok/lipcsei\%20charta_070502.doc

Pieterse, E. (2004) Untangling 'Integration' in Urban Development Policy Debates Published. - Urban Forum. 1. http://www.isandla.org.za/papers/Ubn\%20Integration\%20pap.pdf

\section{EXPERIENCES OF INTEGRATIVE CITY POLICY IN DOMESTIC CITY AREAS}

\section{GYÖNGYVÉR HERVAINÉ SZABÓ}

During the last decade a new urban movement emerged in the European Union and in the member countries. Discourses about integrative urban policies became evident in the European normative texts. The new member states suffer from different urban inequalities and the lack of coherent national urban policies. Recent research about Hungarian experience covered 9 city region areas and 86 local governments. The results are useful for strengthening the competitiveness of Hungarian cities and its surroundings. Hungarian cities adapted a series of integrative technics, but a coherent urban public policy is missing at national level. Hungarian local government leaders need more knowledge about experience and development potential of new urban policy methods, models and technics. The co-operation with other 
local governments is highly underestimated, and there are no practices at the level of subunits. The neoliberal model of local government managerial practices needs other integrative and transformative ones. The legal and organisational competencies are missing at neighbourhood level; there are no practices for community development. The Hungarian local governments have a traditional view of development, there is a strong emphasis on state or local state centred developments and it gives a low value to the capital investment of multinational firms. They are sceptic concerning civil societies and social economy. The main theories about endogenous development and innovation capacity are missing from discourses of local leaders (the role of higher education institutions, research and technology transfer firms). The highly fragmented local government system seems not only ineffective but problematic in adapting innovative practices as well as. 